Special Issue: Agricultural Productivity and Sustainability Improvement in Tropical Region

\title{
Effect of Urea in Total Mixed Ration and its Silage on Friesian Holstein Bull Calves Productivity in Tropic Condition
}

\author{
Ahmad Wahyudi ${ }^{*}$, Sujono Sujono ${ }^{2}$, Listiari Hendraningsih ${ }^{2}$, Ari Prima ${ }^{2}$, Zane Vincēviča-Gaile ${ }^{3}$ and \\ Ivar Zekker ${ }^{4}$
}

${ }^{1}$ Department of Agriculture Sciences, Directorate of Post Graduate Program, University of Muhammadiyah Malang, Jl Raya Tlogomas 246 Malang 65144, Indonesia; ${ }^{2}$ Department of Animal Science, Faculty of Agriculture and Animal Sciences, University of Muhammadiyah Malang, Jl Raya Tlogomas 246 Malang 65144, Indonesia; ${ }^{3}$ Department of Environmental Science, University of Latvia, Jelgavas Street 1, Room 302, Riga LV-1004, Latvia; ${ }^{4}$ Institute of Chemistry, University of Tartu, Ravila 14 a 50411 Tartu, Estonia.

Abstract | Urea addition into feed to some extent has been shown to increase crude protein content and improve feed efficiency. However, its addition in Total Mix Ration (TMR) and also TMR silage on calves' growth performance is yet to be elaborated. Therefore, the effect urea addition on TMR and its silage on performance of Friesian Holstein $(\mathrm{FH})$ male calves were evaluated. The calves ( $\mathrm{n}=27 ; 5 \mathrm{mo}$ to $7 \mathrm{mo}$, mo $=$ month old) were divided into three groups, each group consisted of nine calves, based on age: 5 mo (100 kg to $105 \mathrm{~kg}), 6 \mathrm{mo}(111 \mathrm{~kg}$ to $116 \mathrm{~kg})$, and $7 \mathrm{mo}(123 \mathrm{~kg}$ to $133 \mathrm{~kg})$. All groups were divided into three types of feed, namely: conventional feed containing concentrate and forage without urea (CON), TMR, and TMR silage containing $1.5 \%$ urea. The variables have been observed were feed intake and digestibility of dry matter $(\mathrm{DM})$ and organic matter (OM) and average daily gain (ADG). The data were analyzed using Analysis of Variance (ANOVA) and followed by Least Significant Difference (LSD) test. The average DM intake $(\mathrm{kg}$ head $^{-1}$ day $\left.^{-1}\right)$ for CON, TMR, and TMR silages were 5.15; 6.79; and 4.14 meanwhile OM intakes were 4.68; 6.04; and 3.94 respectively, TMR significantly higher than others $(P<0.05)$. Digestibility of DM and OM (\%) showed the same pattern, TMR followed by CON then TMR silage $(64.09 ; 62.98 ; 54.21$ for DMD) and 73.92; 75.99; 63.78 for OMD. The age has non-significant effect into digestibility. Highest ADG $\left(\mathrm{kg} \mathrm{head}^{-1}\right.$ day $^{-1}$ ) were was obtained from TMR feed (0.70), followed by CON (0.65) and TMR silages (0.45). The older calves the higher ADG reached $(0.65 ; 0.60$ and 0.55$)$. It could be concluded that addition urea $1.5 \%$ in TMR could increase calves' performances, but on the contrary when it added to TMR silage.

Received | January 06, 2021; Accepted | October 21, 2021; Published | October 27, 2021

*Correspondence | Ahmad Wahyudi, Department of Agriculture Sciences, Directorate of Post Graduate Program, University of Muhammadiyah Malang, J1 Raya Tlogomas 246 Malang 65144, Indonesia; Email: wahyudi_biotek@yahoo.co.id

Citation | Wahyudi, A., S. Sujono, L. Hendraningsih, A. Prima, Z.V. Gaile and I. Zekker. 2021. Effect of urea in total mixed ration and its silage on friesian holstein bull calves productivity in tropic condition. Sarhad Journal of Agriculture, 37(Special issue 1): 84-89.

DOI | https://dx.doi.org/10.17582/journal.sja/2021/37.s1.84.89

Keywords | Feeding management, Feed efficiency, Nutritional balanced diet, Optimizing calves' growth, Sustainability dairy farm

\section{Introduction}

$\mathrm{T}$ otal mixed rations (TMR) are produced by mixing forages, byproducts, concentrates, minerals, vitamins, and additives (Bueno et al., 2020). Friesian
Holstein (FH) male calves could be used as a potential meat source due to the higher average daily gain (ADG) compared to Indonesian local cattle like Ongole crossbreed ( 0.86 to $0.92 \mathrm{~kg}$ head $^{-1}$ day $^{-1} \mathrm{vs} 0.33$ to $0.64 \mathrm{~kg} \mathrm{head}^{-1} \mathrm{day}^{-1}$; (Putra et al., 2018). But in $2021 \mid$ Volume 37 | Special Issue 1 | Page 84 
many dairy farms in Indonesia, male calves tend to grow less optimally, and can lead to high morbidity and mortality (Hendraningsih et al., 2015).

For achieving target performance, bull growth is affected by many factors, and feeding management is one of the most important. In order to meet satisfy growth, to maintain decent condition of the body, and to reach an expected height and weight, calves rations must need to be balanced. Therefore, feeding system that has balanced nutrients is essential for optimizing calves' growth which leads to ensure the sustainability of dairy farm business. In conventional feeding system, feed-stuffs such as forage and concentrate are fed separately. Thus, selection of feed occurs, and tends to reduce the quantity of feed intake. Maekawa et al. (2002) reported that cows tended to consume high portion of concentrate in the conventional feeding, and could lead to increase rumen acidosis risk (Beauchemin et al., 2002). To avoid that condition, Total Mix Ration feeding gives a better option. In contrast to adding concentrate to forage feeding, TMR feeding gives a chance for animals to get a complete nutritional balanced diet (Schingoethe, 2017). TMR improves condition of rumen, stabilizes rumen $\mathrm{pH}$, and makes ideal atmosphere for rumen microbes. Feeding TMR to dairy cattle were reported to improve ruminal digestion, passage rate and intake of dry matter (DM; Soriano et al., 2001). Nissanka et al. (2010) suggested that feed selection by young cattle could be avoided by feeding TMR for young cattle, that result better balance nutrient intake. The TMR in Indonesia consists of agro industrial by products, that are often deficient in protein. Protein insufficiency in TMR could be fixed by urea addition. Urea is a source of non-protein nitrogen (NPN) that is accessible, cheap and used as feed supplement to increase feed protein. The amount of urea that included in feed for cattle or sheep should not exceed $3 \%$ and usually the addition of $1 \%$ to $1.5 \%$ will prove adequate (Panday, 2011), meanwhile Currier et al. (2004) suggested that urea can be added up to $6.7 \%$ as long as animal and dietary factors are ideal.

The evaluation of TMR feeding for lactating cattle has often been conducted, but the effect of TMR on calves' growth performance is yet to be elaborated. To preserve the nutrient content, TMR that consist of wet by-product should be ensilaged. Ensiled TMR is able to maintain its nutrient content (Wahyudi et al., 2017) and also can improve the conservation of wet forages (Bueno et al., 2020). Xu et al. (2010) stated that TMR silage could reduce the energy cost related to drying of wet industrial by-product. This study was carried out to find out the impact of TMR and TMR silage with urea addition on nutrient digestibility and $\mathrm{ADG}$ of $\mathrm{FH}$ male calves under tropical environment was undertaken.

Table 1: Ingredient and nutrient compositions of treatment feed.

\begin{tabular}{|c|c|c|c|c|c|}
\hline \multirow[t]{2}{*}{ Ingredients } & & \multicolumn{3}{|c|}{ Treatments Diets } & \multirow{2}{*}{$\begin{array}{l}\text { Nutrient require- } \\
\text { ments of post- } \\
\text { weaning calf }\end{array}$} \\
\hline & & TMR & $\begin{array}{l}\text { TMR } \\
\text { Silage }\end{array}$ & $\mathrm{CON}$ & \\
\hline Wheat bran & $\%$ & - & - & 27.30 & \\
\hline Rice bran & $\%$ & 38.00 & 38.00 & 26.00 & \\
\hline Copra meal & $\%$ & 36.00 & 36.00 & 9.75 & \\
\hline Corn meal & $\%$ & 12.00 & 12.00 & - & \\
\hline Molasses & $\%$ & 3.00 & 3.00 & 1.63 & \\
\hline Peanut hull & $\%$ & 8.50 & 8.50 & - & \\
\hline Urea & $\%$ & 1.50 & 1.50 & - & \\
\hline Minerals & $\%$ & 1.00 & 1.00 & 0.33 & \\
\hline WPC & $\%$ & - & - & 35.00 & \\
\hline
\end{tabular}

Nutrient

Composition*

Dry matter $\quad \% \quad 88.32 \quad 48.02 \quad 60.75 \quad 86.00$

$\begin{array}{llllll}\text { Ash } & \% & 10.01 & 11.29 & 6.55 & 12.00\end{array}$

$\begin{array}{lllll}\text { Organic matter } \% 89.99 & 88.71 & 93.45 & 88.00\end{array}$

Crude protein $\quad \begin{array}{lllll}15.52 & 14.64 & 14.02 & \geq 12.00\end{array}$

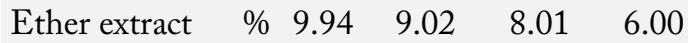

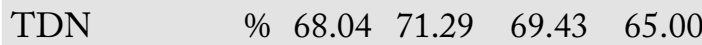

$C O N=$ conventional feed with concentrate $: W P C=65: 35, W P C=$ whole plant corn.

*Nutrition Laboratory of University of Muhammadiyah Malang.

** Directorate of Animal Feed, Department of Agriculture of Republic Indonesia, 2014.

\section{Materials and Methods}

\section{Feed preparation}

The study was conducted at in the Experimental Farm, University of Muhammadiyah Malang, East Java, Indonesia. Feedstuff ingredients were formulated for treatment feed that provided during the experimental period. Feed that prepares for the study were conventional feed $(\mathrm{CON})$ consist of whole plant corn (WPC) and concentrate with 60:40 ratio, TMR, and TMR silage. Ingredient and nutrient composition of treatment feed is presented in Table 1. 
Table 2: Feed intake (kg) and nutrient digestibility (\%).

\begin{tabular}{|c|c|c|c|c|c|}
\hline \multirow[t]{2}{*}{ Variables } & \multirow[t]{2}{*}{ Diets } & \multicolumn{3}{|c|}{ Age (Month) } & \multirow[t]{2}{*}{ Average } \\
\hline & & 5 & 6 & 7 & \\
\hline \multirow[t]{4}{*}{ DM intake (kg) } & $\mathrm{CON}$ & $5.05 \pm 0.43$ & $5.07 \pm 0.39$ & $5.33 \pm 0.41$ & $5.15 \pm 0.40^{\mathrm{b}}$ \\
\hline & TMR & $5.55 \pm 0.91$ & $7.38 \pm 0.95$ & $7.46 \pm 0.72$ & $6.79 \pm 0.81^{\mathrm{a}}$ \\
\hline & TMR Silage & $4.60 \pm 0.44$ & $4.07 \pm 0.49$ & $3.75 \pm 0.27$ & $4.14 \pm 0.34^{c}$ \\
\hline & Average & $5.06 \pm 0.62^{\mathrm{B}}$ & $5.50 \pm 0.77^{\mathrm{A}}$ & $5.51 \pm 0.55^{\mathrm{A}}$ & \\
\hline \multirow[t]{4}{*}{ OM intake (kg) } & $\mathrm{CON}$ & $4.59 \pm 0.39$ & $4.62 \pm 0.33$ & $4.84 \pm 0.34$ & $4.68 \pm 0.36^{\mathrm{ab}}$ \\
\hline & TMR & $4.93 \pm 0.74$ & $6.56 \pm 0.77$ & $6.63 \pm 0.58$ & $6.04 \pm 0.67^{a}$ \\
\hline & TMR Silage & $4.14 \pm 0.38$ & $3.87 \pm 0 . .43$ & $3.57 \pm 0.23$ & $3.94 \pm 0.31^{b}$ \\
\hline & Average & $4.63 \pm 0.53^{\mathrm{B}}$ & $5.01 \pm 0.57^{\mathrm{A}}$ & $5.01 \pm 0.47^{\mathrm{A}}$ & \\
\hline \multirow[t]{4}{*}{ DM digestibility (\%) } & $\mathrm{CON}$ & $66.0 \pm 13.40$ & $62.92 \pm 7.69$ & $60.02 \pm 6.75$ & $62.98 \pm 9.41^{a}$ \\
\hline & TMR & $61.97 \pm 4.78$ & $64.04 \pm 1.56$ & $66.26 \pm 3.01$ & $64.09 \pm 2.77^{a}$ \\
\hline & TMR Silage & $51.53 \pm 8.31$ & $57.80 \pm 5.12$ & $53.30 \pm 7.33$ & $54.21 \pm 6.32^{\mathrm{b}}$ \\
\hline & Average & $59.83 \pm 9.59^{\mathrm{ns}}$ & $61.58 \pm 4.53^{\mathrm{ns}}$ & $59.86 \pm 5.45^{\mathrm{ns}}$ & \\
\hline \multirow[t]{4}{*}{ OM digestibility (\%) } & $\mathrm{CON}$ & $77.66 \pm 7.11$ & $74.03 \pm 9.24$ & $70.38 \pm 5.61$ & $73.92 \pm 6.21^{a}$ \\
\hline & TMR & $72.91 \pm 9.31$ & $77.11 \pm 5.26$ & $77.96 \pm 6.22$ & $75.99 \pm 6.33^{a}$ \\
\hline & TMR Silage & $68.01 \pm 11.20$ & $60.63 \pm 8.14$ & $62.72 \pm 10.21$ & $63.78 \pm 9.12^{b}$ \\
\hline & Average & $72.88 \pm 9.71^{\mathrm{ns}}$ & $70.59 \pm 7.34^{\mathrm{ns}}$ & $70.35 \pm 7.58^{\mathrm{ns}}$ & \\
\hline
\end{tabular}

$C O N=$ Conventionalfeed, $T M R=$ Total Mix Ration, $T M R S=T M R$ Silage, $D M=$ dry matter, OM= organic matter .

The experimental diets were formulated based on $15 \%$ of crude protein (CP) and $68 \%$ total digestible nutrient (TDN). Each feed was given ad libitum twice a day at 07.00 and 15.00 .

\section{Samples collection and nutrients analysis}

Feed intake was measured daily and weight gain was taken weekly for individual calf. Feces were collected in final $3 \mathrm{~d}$ consecutively each week and stored for analyses. Approximately $100 \mathrm{~g}$ of daily fecal excretion from each calf were subsampled into a plastic bag, and dried at $65^{\circ} \mathrm{C}$ for $48 \mathrm{~h}$ and ground to pass a $1 \mathrm{~mm}$ screen with a Grinder-mixer (Panasonic MXAC400, Japan). The dry matter (DM), organic matter $(\mathrm{OM})$, crude protein $(\mathrm{CP})$, and ether extract (EE) of feed, leftover feed, and feces were analyzed according to AOAC.

\section{Research design}

A total of 27 post weaned Friesian male calves were divided into three groups based on age, each group consisted of nine calves, i.e. $5 \mathrm{mo}(100 \mathrm{~kg}$ to $105 \mathrm{~kg}$, $6 \mathrm{mo}(111 \mathrm{~kg}$ to $116 \mathrm{~kg})$ and $7 \mathrm{mo}(123 \mathrm{~kg}$ to $133 \mathrm{~kg})$. Each group contains three replicates, and each replicate consists of three calves. At the beginning of this study, all animals were in good condition and validated by a veterinarian. Each bull was housed individually in a pen designed to protect animals from weather and feed bins from rain. Feed was weighed and of- fered twice daily at 7 am and $3 \mathrm{pm}$. The availability of water was always kept ad-libitum to the calves through-out the day. A preliminary period of $2 \mathrm{wk}$ (week) was given to acclimatized the calves with the feeding and housing. Male calves were kept for 3 mo. Feed intake was recorded daily and daily gains were measured and recorded at $6^{\text {th }}, 8^{\text {th }}$, and $10^{\text {th }}$ week.

The data were analyzed using Analysis of Variance (ANOVA) and followed by Least Significant Difference (LSD) test if the ANOVA has any significant or very significant effect (Adinurani, 2016).

\section{Results and Discussion}

\section{Feed intake and digestibility}

The result showed that intake of DM and OM of TMR was higher than other feeds (Table 2). This study was in line with Lailer et al. (2010) and Teshome et al. (2017) who reported that TMR significantly improves DM intake. This result also supported by studies of Beigh et al. (2017) and Sharma et al. (2010). Pandya et al. (2005) stated that smaller particle in TMR leads to increase palatability and DM intake. The increase in DM intake was also observed with molasses-based liquid TMR in lactating cattle (De Vries and Gill 2012). These results are in accordance with Chander (2011) and Khan et al. (2010), that intake of DM and CP from pellet TMR is higher 
than conventional feeding. Moreover, total mixed ration based on urea ammoniated straw increased the intake of DM compared to feeding wheat straw and concentrate individually (Pachauri et al., 2010).

Unexpectedly, intake of TMR and OM is lowest in TMR silage to CON and TMR group. Silage that made from wet agricultural by product tends to have low DM content. Schingoethe et al. (2009) concluded that DM is insufficient when feeding large amounts of ensiled forages and wet by-products, such as wet distiller grains. High moisture in TMR silages, tend to alter the pattern of fermentation that followed by greater accumulation in fermentation end products, and proteolysis (Bueno et al., 2020). Along with high water content, urea addition in this study was predicted to lead to butyric acid formation by clostridia in the silage. Kung et al. (2018) explain that high-moisture silages have higher concentrations of soluble $\mathrm{N}$ and $\mathrm{NH}_{3}-\mathrm{N}$ than drier silages resulting from proteolytic activity from clostridia. Clostridial activity is undesirable for several reasons; produce ammonia like odor, fishy, and putrid (Kung et al., 2018), decrease the palatability and depress intake (Muck, 2010).

Calves age did not influence the DM intake, but contradict with CON and TMR group that showed increasing along with the age, intake of TMR Silage decrease. In younger calves' group, butyric acid content in the silage was predicted to be used for rumen development. Bedford and Gong (2018) stated that in early post weaning, young ruminants, butyric acid is used for development of rumen papillae. This result also supported by Serbester et al. (2014) study indicates that the DM intake tends to decrease in post weaned calves with butyric addition in the feed. Intake of OM showed the same response to the diets as of DM. The intake of OM is strongly influenced by DM intake (Prima et al., 2018).

Poor silage produced in this study was predicted to not only influence the intake but also the digestibility. Calves fed with TMR Silage diet had the lowest digestibility of DM and OM. Oliveira et al. (2016) concluded that silage digestibility is affected by ensiling process. Ensilage produces ammonia that enters the $\mathrm{N}$ recycling cycle of the calves, and depresses intake of DM and increase the animal energy costs. This mechanism seems to be the case in this study. Urea addition in TMR has good effect and tends to increase the $\mathrm{N}$ availability, but on the other hand in contrast not toward in the silage. The low dry matter content of silage as that already mentioned in this study above could be also the factor that depresses the digestibility, because it leads to butyric acid formation by clostridia. Concentration of butyric acid is negatively correlated with digestibility (Oliveira et al., 2016).

The data on performance of animals is presented in Table 3. Higher ADG was reached by TMR group followed by CON and TMR Silage. This was in accordance with DM and OM intake and also digestibility in this study. Showed that TMR has highest value than to the other feeds. High intake and digestibility will provide sufficient nutrients that would be converted into production or ADG. These results are consistent with Liu et al. (2016) that DM intake and ADG Limousine fed TMR is higher than group fed with separate TMR silage and concentrate.

Table 3: Average daily gain.

\begin{tabular}{lllllll} 
Parameter & Feeds & \multicolumn{3}{l}{ Age (month) } & Average \\
& Diets & $\mathbf{5}$ & $\mathbf{6}$ & $\mathbf{7}$ & \\
ADG $(\mathrm{kg})$ & CON & 0.57 & 0.64 & 0.74 & $0.65^{\mathrm{b}}$ \\
& TMR & 0.52 & 0.71 & 0.89 & $0.70^{\mathrm{a}}$ \\
& TMR Silage & 0.57 & 0.45 & 0.33 & $0.45^{\mathrm{c}}$ \\
& Average & $0.55^{\mathrm{c}}$ & $0.60^{\mathrm{b}}$ & $0.65^{\mathrm{a}}$ &
\end{tabular}

$C O N=$ Conventional feed, $T M R=$ Total Mix Ration, $T M R S=$ TMR Silage

\section{Conclusions and Recommendations}

Additional of $1.5 \%$ urea in TMR increased both dry matter and organic matter of intake compare to conventional feeding, but contrary effect found from urea use in TMR silage. Calves from TMR and CON treatments had significantly higher dry matter and organic matter digestibility. Age has non-significant effect into digestibility. TMR feed gave highest ADG when it compared to CON and TMR silages feed. While the older calves the higher ADG reached.

\section{Novelty Statement}

Feeding, in the form total mix ration (TMR) to cattle, is increasingly done by farmers in Indonesia. Urea supplementation has been widely used in cattle feed formulation, due to the cheaper crude protein resources and it can improve feed efficiency. But, the 
addition of urea in TMR and also its silage on calves' growth performance is yet to be elaborated.

\section{Author's Contribution}

AW conceptualized and designed the study, elaborated the intellectual content, performed literature search, data acquisition, data analysis, statistical analysis, and manuscript preparation. SS and LH defined the intellectual content, carried out literature search, manuscript review and manuscript revision. AP carried out experimental studies and manuscript review. $\mathrm{ZV}-\mathrm{G}$ and $\mathrm{IZ}$ elaborated the intellectual content, performed literature search, performed manuscript review/revision and guarantor.

\section{Conflict of interest}

The authors declares that there is no conflict of interests regarding the publication of this article.

\section{Reference}

Adinurani, P.G. 2016. Design and analysis of agro trial data: Manual and SPSS. Plantaxia, Yogyakarta, Indonesia.

Beauchemin, K.A., M. Maekawa and D.A. Christensen. 2002. Effect of diet and parity on meal patterns of lactating dairy cows. Can. J. Anim. Sci. 82(2):215-223. https://doi.org/10.4141/ A01-080

Bedford, A. and J. Gong. 2018. Implications of butyrate and its derivatives for gut health and animal production. Anim. Nutr., 4(2):151-159. https://doi.org/10.1016/j.aninu.2017.08.010

Beigh, Y.A., A.M. Ganai and H.A. Ahmad. 2017. Prospects of complete feed system in ruminant feeding: A review. Vet. World, 10(4): 424-437. https://doi.org/10.14202/vetworld.2017.424-437

Bueno, A.V.I., G. Lazzari, C.C. Jobim and J.L.P. Daniel.2020. Ensiling total mixed ration for ruminants: A review. Agronomy, 10 (6) 879:1-18. https://doi.org/10.3390/agronomy10060879

Chander, M. 2011. Chaff cutters and fodder chaffing: A simple technology worth adoption. p. 133-136. In: Makkar, H.P.S. (ed.). Proceedings of FAO E-Conference on, Successes and Failures with Animal Nutrition Practices and Technologies in Developing Countries. Food and Agriculture Organization of the United Nations, Rome.
Currier, T.A., D.W. Bohnert, S.J. Falck and S.J. Bartle. 2004. Daily and alternate day supplementation of urea or biuret to ruminants consuming low-quality forage: Effects on cow performance and the efficiency of nitrogen use in wethers. J. Anim. Sci., 82 (5):1508-1517. https://doi. org/10.2527/2004.8251508x

DeVries, T.J. and R.M. Gill. 2012. Adding liquid feed to a total mixed ration reduces feed sorting behavior and improves productivity of lactating dairy cows. J. Dairy Sci., 95(5): 2648-2655. https://doi.org/10.3168/jds.2011-4965

Dong, L., B. Li and Q. Diao. 2019. Effects of dietary forage proportion on feed intake, growth performance, nutrient digestibility, and enteric methane emissions of Holstein heifers at various growth stages. Animals, 9(10): 725:1-14. https://doi.org/10.3390/ani9100725

Hendraningsih, L., C.I. Sutrisno, A. Muktiani and B. Sulistyanto. 2015. A survey of preweaning calves practice in smallholder dairy farms in Indonesia. Livestock Res. Rural Dev., 27(5).

Khan, S.R., S.K. Singh and V. Mudgal. 2010. Effect of feeding complete rations on the performance of lactating crossbred cow. Indian. J. Anim. Nutr., 27(3):261-264.

Kung, Jr. L., R.D. Shaver, R.J. Grant and R.J. Schmidt. 2018. Silage review: Interpretation of chemical, microbial, and organoleptic components of silages. J. Dairy Sci., 101(5): 40204033. https://doi.org/10.3168/jds.2017-13909

Lailer, P.C., S.S. Dahiya, L. Madan and D. Lal. 2010. Effect of complete feed blocks on growth performance of Murrah male calves. Indian J. Anim. Nutr., 27(3):220-223.

Liu, Y.F., F.F. Sun, F.C. Wan, H.B. Zhao, X.M. Liu, W. You, H.J. Cheng, G.F. Liu, X.W. Tan and E.L. Song. 2016. Effects of three feeding systems on production performance, $\mathrm{ru}^{-}$ men fermentation and rumen digesta particle structure of beef cattle. Asian-Aus.. J. Anim. Sci., 29(5):659-665. https://doi.org/10.5713/ ajas.15.0445

Maekawa, M., K.A. Beauchemin and D.A. Christensen. 2002. Effect of concentrate level and feeding management on chewing activities, saliva production, and ruminal $\mathrm{pH}$ of lactating dairy cows. J. Dairy Sci., 85(5):1165-1175. https:// doi.org/10.3168/jds.S0022-0302(02)74179-9

Muck, R.E. 2010. Silage microbiology and its control through addi-tives. Rev. Bras. Zootec., 
39:182-191. https://doi.org/10.1590/S151635982010001300021

Nissanka, N.P.C., R.M.A.S. Bandara and K.G.J.S. Disnaka. 2010. A comparative study on feeding of total mixed ration vs conventional feeding on weight gain in weaned Friesian heifers under tropical environment. J. Agric. Sci. 5(1):42-51. https://doi.org/10.4038/jas.v5i1.2331

Oliveira, J.S., E.M. Santos and A.P.M. dosSantos. 2016. Intake and digestibility of silages. p.101121. In: DaSilva, T. and E.M. Santos (eds), Chapter 6. Advances in Silage Production and Utilization. Intech, London, UK. https://doi. org/10.5772/65280

Pachauri, S.K., S.K. Singh and V. Mudgal. 2010. Effect of feeding wheat straw and urea ammoniated wheat straw based total mixed rations on the performance of female crossbred calves. Indian. J. Anim. Nutr. 27(1):73-76.

Panday, D. 2011. Urea as a non-protein nitrogen sources for ruminants. Alltech Young Scientific Competition, USA. pp. 1-13. (https://www.researchgate.net/publication/301618548)

Pandya, P.R., R.S. Gupta, P.M. Talpada, G.R. Patel and M.C. Desai. 2005. Effect of complete feeds based on wheat straw and Prosopisjulifora pods on growth and reproductive performance of growing crossbred heifers. Indian. J. Anim. Sci., 75(1): 56-59.

Prima A., E. Rianto, E. Purbowati, A. Purnomoadi. 2018. Indirect evaluation of digestive tract function on male lambs and ram based on feed digestibility and eating behavior. J. Indonesian Trop. Anim. Agric., 43 (2):124-130. https:// doi.org/10.14710/jitaa.43.2.124-130

Putra,W.P.B., P. Agung and S. Said. 2018. Non-genetic factor and genetic parameter analysis for growth traitsin Sumba Ongole (SO) cattle. J. Indonesian Trop. Anim. Agric., 43(2): 94-106. https://doi.org/10.14710/jitaa.43.2.94-106
Schingoethe, D.J. 2017. A 100-Year Review: Total mixed ration feeding of dairy cows. J. Dairy Sci., 100(12):10143-10150. https://doi. org/10.3168/jds.2017-12967

Schingoethe, D.J., K.F. Kalscheur, A.R. Hippen and A.D. Garcia. 2009. Invited review: The use of distillers products in dairy cattle diets. J. Dairy Sci., 92(12):5802-5813. https://doi. org/10.3168/jds.2009-2549

Serbester, U, C. Çakmakci, S. Goncu and M. Gorgulu. 2014. Effect of feeding starter containing butyrate salt on pre- and post-weaning performance of early or normally weaned calves. Revue Méd. Vét., 165(1-2): 44-48.

Sharma, D., D.P. Tiwari and B.C. Mondal. 2010. Performance of crossbred female calves fed complete ration as mash or block vis-a-vis conventional ration. Indian J. Anim. Sci., 80(6):556-560.

Soriano, F.D., C.E. Polan and C.N. Miller. 2001. Supplementing pasture to lactating Holsteins fed a total mixed ration diet. J. Dairy Sci. 84(11):2460-2468. https://doi.org/10.3168/ jds.S0022-0302(01)74696-6

Teshome D., L. Fita, F. Feyissa, G. Kitaw and Z. Wondati. 2017. Effect of total mixed ration on dry matter intake, milk yield and composition of early lactating Jersey Cows. J. Biol. Agric. Healthcare, 7(9):19-24.

Wahyudi, A., D. Pamungkas, R.H. Setyobudi, L. Hendraningsih and Z. Vincevica-Gaile. 2017. Organic acid and nutrient composition of lactic acid bacteria inoculated total mixed ration silage under tropical condition Proc. Pakistan Acad. Sci Part B, 54 (1):41-45.

Xu, C., Y. Cai, J. Zhang and H. Matsuyama. 2010. Feeding value of total mixed ration silage with spent mushroom substrate. Anim. Sci. J., 81(2):194-198. https://doi.org/10.1111/ j.1740-0929.2009.00728.x 